\title{
The Concept of Khudi (The Self) in Iqbal's The Secrets of the Self
}

\author{
Aurang Zeb (Corresponding author) \\ Govt. College University, Faisalabad, Pakistan \\ Email: zebchattha@gmail.com \\ Khamsa Qasim \\ Govt. College University, Faisalabad, Pakistan
}

\author{
Doi:10.7575/aiac.alls.v.6n.3p.202 \\ URL: http://dx.doi.org/10.7575/aiac.alls.v.6n.3p.202
}

Received: $16 / 02 / 2014$

Accepted: 27/04/2015

\begin{abstract}
This article is an attempt to study the concept of "Khudi" in Iqbal's The Secrets of the Self not only on theoretical grounds but also on account of its poetic expression. This research article focuses upon Iqbal's inventive doctrine of the self; and all the subsequent works of Iqbal supplemented and further refined this central concept. The dominant idea that Iqbal emphasizes is that knowing oneself is in fact an immediate perception of God. He focuses his attention on the individual "I", thus shifting the emphasis from divine to human. The path of recognition of the self is the path that takes one to a contact with the Absolute. Iqbal's whole conception of the growth of the selfhood consists of three levels:

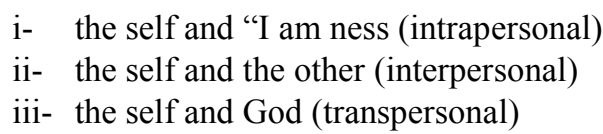

The first level of the self and "I am ness" can be likened to the first (lowermost) level of psychological needs in Maslow's Hierarchy of Needs. At this level the self is just conscious of its own self. This "I am ness" marks the first awakening of the self. The self cannot think beyond itself until and unless the physiological needs are satisfied. The other level of "the self and the other" can be linked to psychological and social needs. After the station of the biological or physiological needs, the self yearns for security and stability. Here, at this level, the self is able to recognize the other that is to see oneself in the light of the other. When physiological and safety needs are fairly satisfied as Maslow suggests, "People have belongingness and love needs---they feel the need that they belong somewhere instead of being transient or newcomers---“(Hall 204). Relatedness is a need of belongingness, which starts from our natural ties with our mother and reaches to universal comradeship with all human beings. The third level of "the self and God" is the recognition of God---to see oneself in the light of God. This level can be linked to the "Need of self-actualization" in Maslow's theory. The development of the self does not take place in a void or seclusion. When a man is disconnected from his environments, his capacities remain underdeveloped. Iqbal's "Perfect Man" at the highest level of selfrealization attains a spiritual power. The absorption of the Divine attributes makes the Perfect Man closer to God. So the self attains its highest goal by becoming deeply related to God, making possible a union of the temporal and the eternal. He then knows that the world has been created for him and he is for the world.
\end{abstract}

Keywords: Khudi (The Self), Secrets, Intrapersonal, Interpersonal, Transpersonal, Man, God, Universe, Spiritual

\section{The Concept of Khudi (The Self) In Iqbal's The Secrets Of The Self}

Iqbal's poetry appeared in the twentieth century---a crucial time for the people of the sub-continent in the wake of British colonization and World War I. He was deeply concerned with the revival of the lost identity and status of the Muslims. Iqbal was despaired with the Muslim religious-philosophic tradition of his time which he termed in Reconstruction of Religious Thoughts in Islam as "worn out and practically dead metaphysics" (Iqbal 125) with its peculiar thought form and phraseology producing "a deadening effect on the modern mind" (Iqbal 125). His vibrant poetry stirred the dead into life and infused a renewing and rejuvenating sense of identity and self-manifestation in his readers.

The Secrets of the Self (first published in 1915) marks the underpinning of a new stage in Iqbal's creative work. It is linked with the turning point of Iqbal's stance which took place after the poet's homecoming from Europe. The poem contains Iqbal's inventive doctrine of the self; and all the subsequent works of Iqbal supplemented and further refined this central concept. Before giving an interpretation of the poem, it is but seminal to look into what, Iqbal himself said about the poem. While dictating his views to Nazir Niazi in 1937, Iqbal explicitly stated that the poem is based on two principles:

(a) that the personality is the central fact of the universe; (b) that personality "I am" is the central fact in the constitution of man. The first principle is described in the Old Testament "as the great I am". The second 
principle of the smaller or dependent I-am is various described in Quran as weak or ignorant yet it is also described as the bearer of the Divine trust---, it has the quality of growth as well as corruption, it has the power to expand by absorbing the elements of the universe of which it appears to be an insignificant part, it has also the power of absorbing the attributes of God (Wahid Thoughts and Reflection of Iqbal243).

This personal observation of Iqbal serves as a gateway to the landscapes of meaning. The dominant idea that Iqbal emphasizes is that knowing oneself is in fact an immediate perception of God. He focuses his attention on the individual "I", thus shifting the emphasis from divine to human. The path of recognition of the self is the path that takes one to a contact with the Absolute. As he writes in introduction to The Secrets of the Self translated by Nicholson:

Physically and spiritually man is self-contained centre, but he is yet a complete individual. The greater his distance from God, the less is his individuality. He who comes nearest to God is the complete person. Nor that he is finally absorbed in God. On the contrary he absorbs God in himself (Nicholson xix).

Subverting the traditional concept of mystical experience, Iqbal transfigured it as the fully developed self that does not dissolve even when the reality is seen face to face in mystical experience. And what he actually means by the idea of "absorbing God in himself" is to cultivate and create the attributes of God and by doing this "the man becomes unique by becoming more and more like the most unique individual" (Nicholson viii). It is only after self-realization that the real meaning and purpose of human existence becomes more clear.

In psychology, the Humanistic school with its most prominent figure Maslow recognizes this human potential for self actualization. Maslow defines self-actualization as:

Ongoing actualization of potentials, capacities and talents, as fulfillment of mission (or call, fate, destiny or vocation), as fuller knowledge of, and acceptance of, the person's own intrinsic nature, as an unceasing trend towards unity, integration or synergy within the person (Cloninger 441).

Maslow postulated a hierarchical theory that is often represented as a pyramid, with the lower levels representing lower needs, and the upper point representing the need for self-actualization. Susan Cloninger explains in Theories of Personality: understanding Persons: "This hierarchy consists of five levels: four levels of deficiency motivation and a final, highly developed level called being motivation or self-actualization" (Cloninger 436). Maslow divides these needs into two main classes: D-Needs and B-Needs: D-Needs mean that whenever there is deficiency in the fulfillment of these needs there is a motivation to eliminate them. B-Needs are the self actualizing needs concerned with the need to know Truth.

Maslow saw human needs arranged like a ladder. The highest one is the need for self-actualization but that cannot be reached without stepping the other needs of this ladder. The most basic needs, at the bottom, are physical---air, water, food, sex. Then there are the safety and psychological needs----for belonging, love and acceptance. At the top are the need for self-actualization---the need to fulfill oneself and the experience at this stage gained can be called as "peak experience". According to it, "peak experiences" are profound mystical moments of love, understanding, happiness or rapture, when a person feels more whole, alive, self-sufficient and yet a part of the world, more aware of truth, justice, harmony, goodness and so on.

Maslow's hierarchy of needs is based on the universal fact about human nature. Man's spiritual needs are undeniable and without moral and ethical concepts life is empty. There is a lot of truth in the maxim that "man does not live by bread alone"; though the converse is much true and as much applicable that man cannot live without bread. The human self can develop and prosper only when his basic needs are properly and adequately supplied. He must have sufficient clothing and a house to live. These are the primary adjuncts of life and their absence retards the growth of the self. These are the basic physical demands and the need for these is not only pressing but universal.

Iqbal also takes into consideration the importance of these needs. He does not deny them as is the case with the traditional mysticism based on asceticism. As study of Iqbal's poetry and prose reveals that he believes that the individual has potential to develop his personality to its full capacity. The society plays a dominant role in developing human personality. The self cannot develop in vaccum. Iqbal states in Reconstruction of Religious Thought in Islam:

It is our reflective contact with the temporal flux of things which train us for an intellectual vision of the nontemporal. Reality lives in its own appearances, and such a being as man, who has to maintain his life in an obstructing environment, cannot afford to ignore the visible (Iqbal 14).

Iqbal emphasizes the paramount place of the physical world in an effort to realize the spiritual ideal of growth of the selfhood.

Iqbal's whole conception of the growth of the selfhood consists of three levels:

iv- the self and "I am ness (intrapersonal)

$\mathrm{v}$ - the self and the other (interpersonal)

vi- the self and God (transpersonal) 
These levels have been wonderfully described by Iqbal in JavedNamain an excerpt that he himself placed at the end of his philosophic masterpiece The Reconstruction of Religious Thought in Islam:

Art thou in the stage of "life", "death" or "death-in-life",

Invoke the aid of three witnesses to verify thy station,

The first witness is thine own consciousness-

--see thyself, then with thine own light

The second witness is the consciousness of another ego---

See thyself, then with the light of an ego other than thee,

See thyself then with God's light---

If thou standest unshaken in front of this light,

Consider thyself as living and eternal as He!

That man only is real who dares---

Dares to see God face the face---

No one can stand unshaken in His presence;

And he who can, verily, he is pure gold,

Art thou a mere particle of dust?

Tighten the knot of thy ego;---

Rechisel then, thine ancient frame;

And build up a new being.

Such being is real being;

Or else thy ego is mere ring of smokes (Iqbal 157).

The first level of the self and "I am ness" can be likened to the first (lowermost) level of psychological needs in Maslow's Hierarchy of Needs. At this level the self is just conscious of its own self. This "I am ness" marks the first awakening of the self. The self cannot think beyond itself until and unless the physiological needs are satisfied. In this connection, Maslow's observation is worth mentioning:

When the body has an absolute, unsatisfied needs for food, all other needs will be pushed into background--such a state may even change a person's view of the future, for the seriously hungry person, freedom, love, community, feeling, respect, philosophy and so on may all be waved aside and the person may think if only he or she is guaranteed food for the rest of life, happiness will be complete. But once hunger is satisfied the person will immediately begin to think of other needs (Hall 203).

So these needs are indispensable for the body to function.

According to Maslow's theory, the other level of "the self and the other" can be linked to psychological and social needs. After the station of the biological or physiological needs, the self yearns for security and stability. Here, at this level, the self is able to recognize the other that is to see oneself in the light of the other. When physiological and safety needs are fairly satisfied as Maslow suggests, "People have belongingness and love needs---they feel the need that they belong somewhere instead of being transient or newcomers---"(Hall 204). Relatedness is a need of belongingness, which starts from our natural ties with our mother and reaches to universal comradeship with all human beings. In his book Iqbal Today, Dr. Nazir Qaiser relates the idea:

This need is behind all phenomenon which constitute the whole gamut of intimate human relation of all passions which are called love in the broadest sense of the word-----there is only one passion which satisfies man's need to unite himself with the world, and to acquire at the same time a sense of integrity and individuality and this is love (Qaiser 107)

The development of the self does not take place in a void or seclusion. Iqbal also affirms this universal comradeship with all human beings in the following verse cited by Nazir Qaiser in Iqbal Today: The third level of "the self and God" is the recognition of God---to see oneself in the light of God. This level can be linked to the "Need of self-actualization" in Maslow's theory. When all other needs are satisfied, Maslow states: "A new discontent and restlessness will develop unless the individual is doing he individually is fitted for. A musician must make music, an artist must paint, a poet must write" (Hall 206).

So in Maslow's terms, at the level of self-actualization, an individual is liable to explore his creative potential. This sense of creativity makes him a co-worker with God in Iqbal's terms. For Iqbal, the self-actualization is the cultivation 
of God in human self. Dr. Javed Iqbal writes in this connection: "Iqbal through the constant strengthening of ego (self) expects man to become a Divine Being in creating a more perfect universe" (J. Iqbal 11).

It is the pinnacle of self-actualization and self-realization that endows the self with the moments of great awe, understanding and rapture as characterized by Maslow. Peak experiences may be creative periods or they may be of contemplative nature. Maslow explains:

During a peak experience, the individual not only experiences an expansion of self but also a sense of unity and meaningfulness in his/her existence. For that moment the world appears to be complete, and he or she is at one with it. After the experience is over and the person has returned to the routine of everyday living, the quality that transforms one's understanding so that things do not seem to be quite the same afterward (Maslow in QaiserA Criticism of Western Psychology and Psychotherapy and Iqbal's Approach 96).

Iqbal's "Perfect Man" at the highest level of self-realization attains a spiritual power. The absorption of the Divine attributes makes the Perfect Man closer to God. Dr. Anne Marrie Schimmel rightly observes: "The faithful who has realized in himself the Divine call, and who has consolidated ego (self) so much that he is able to have a person to person encounter with his creator is, for Iqbal, the Perfect Man, the Free Man" (Schimmel in Qaiser A Criticism of Western Psychology and Psychotherapy and Iqbal's Approach 117). He is capable of getting himself in tuned to the Higher Reality in mystical experience. Iqbal delineates the dimensions of such an experience in Reconstruction of Religious Thought in Islam in detail:

The mystic state brings us into contact with the total passage of Reality in which all the diverse stimuli merge into one another and form a single unanalysable unity in which the ordinary distinction of subject and object does not exist------the mystic state is a moment of intimate association with a unique other self----(Iqbal 2324).

So the self attains its highest goal by becoming deeply related to God, making possible a union of the temporal and the eternal. He then knows that the world has been created for him and he is for the world. His self-knowledge makes him more involved into the worldly matters. Iqbal expounds this onward marching of the self towards its realization very comprehensively in The Secrets of the Self. In ongoing pages, this growth of the self would be traced in Iqbal's poem.

In The Secrets of the Self, Iqbal has pictured the infinite potentialities of the human self. He formulates the hierarchic stages in which it can be achieved. "In the poem he has defined what an individual life is, what is its motive power, in what way it should be developed, what is its goal, and how that goal is to be reached" (Ali 208). The creative unfolding of the human self is at the heart of Iqbal's concept of self in the poem.

At the start of the poem, Iqbal invites the readers and gives a call for realization of the selfhood:

This bell calls other travelers to take the road,

No one hath told the secret which I will tell or threaded a pearl of thought like mine

come, if thou would'st know the secret of everlasting life!

Come, if thou would'st win both earth and heaven!

Heaven taught me this lore,

I cannot hide if from comrades.

(The Secrets of the Self: Lines: 42-43, 67-72, P. 4-6)

In a confident and candid tone, the poet invites the readers to taste the secret of eternal life that lies in the realization of selfhood. Moreover, he is certain and sure of the fact that the "bell" he is ringing would be responded positively and this assurance comes from his own strength that he has gathered after mastering self. The use of the word "comrades" again reminds one of Whitman's use of the same word with the spirit of fraternity and bond of love that binds and holds the whole creation and brings them on one level.

After his motivating and inspiring call, Iqbal prepares the reader for an entry into the process of the realization of selfhood.

And advance hotly on a new quest

And become known as the champion of a new spirit;

Take a draught of love's pure wine.

Strike the chords of thine heart and rouse of tumultuous strain.

(The Secrets of the Self: Lines 88-90, 118-20, P. 10-11)

Here Iqbal has given a clue to the reader that the pathway to the realization of the self is demanding and it calls for a life of action and love. Iqbal also explains it in the introductory note to The Secrets of the Self: 
Personality is a state of tension and can continue only if that state is maintained, if the state of tension is not maintained, relaxation will ensue-------that which tends to maintain the state of tension tends to make us immortal (Nicholson xxi).

He has firm faith in the hidden potentiality of the self. Using beautiful similes he poses a deep-seated faith in the expansion of the self:

When a drop of water gets of self's lesson by heart,

It makes its worthless existence a pearl

And when the grass found a means of growth in its self,

Its aspiration clove the breast of the garden.

(The Secrets of the Self: Lines 264-66, P. 22)

It is this consciousness of the self that makes a particle of dust shine like star, a drop of water radiates and sparkles like a pearl and makes a delicate leave of grass sprout through hard ground. When once this consciousness manifests itself, the self moves forward to a continual expansion.

When the self becomes conscious of its significance, it moves one step further to the stage of awakening of the self. In Iqbal's poetry, awakening of the self is characterized by burning the passion of desire and the creation of ideals. Purpose and desire are seminal for the growth of the self towards actualization and realization. Iqbal also emphasizes it in Reconstruction of Religious Thought in Isalm:

Life is only a series of acts of attention, and an act of attention is inexplicable without reference to a purpose, conscious or unconscious. Even acts of perception are determined by our immediate interests and purposes. Thus ends and purposes, whether they exist as conscious or sub-conscious tendencies form the warp and woof of conscious experience (Iqbal 52-53).

Hence purpose preserves the life of the self:

Its (self) origin is hidden in desire

Keep desire alive in thy heart,

Lest thy little dust become a tomb

Desire keeps the self in perpetual uproar

It is restless wave of the self's sea

Negation of desires is death to the living

Even as absence of heat extinguishes the flame

Rise intoxicated with the wine of an ideal,

An ideal shining as the dawn

(The Secrets of the Self: Lines 270-73, 283-85, 287-89, 314-15)

The recognition of the self serves as a gateway to the noble objectives of existence. A burning passion of desire, a longing and yearning is required for the realization of these objectives. Thus to Iqbal, awakening of the self means a life fraught with meaning, purpose and ideal; without it, is dreariness, decay and finally death. In Iqbal's poetry awakening occurs through the burning passion of desire---the desire to explore, discover and bring to light the secrets and mysteries of existence. Yearning is therefore the soul of the world:

We live by forming ideal,

We glow in the sun-beams of desire

(The Secrets of the Self: Lines 321, 322, P. 27).

According to Iqbal, desire is the spring from which the self draws sustenance. Dr. Raffat Hassan observes; "Iqbal calls desire by several names suz, hasrat, justuju. Desire is a creative power even when it remains unfulfilled" (Habib 50).

This awakening of the self with the burning passion of desire leads it to the process of purification. It purges itself with the magical power of love. The road to the self is the road of love. Only true love can instill faith in man's soul and lead him to the deep apprehension of the Divine:

The luminous point whose name is the self

Is the life-spark beneath our dust

By love it is made more lasing,

More living, more burning, more glowing 
From love proceeds the radiance of its being

And the development of its unknown possibilities

Its nature gathers fire from love

(The Secrets of the Self: Lines 323-29, P. 28)

In the philosophy of Iqbal, love is a much broader passion. It is the greatest force in human life-----and essence and nectar of life that can obliterate death. Iqbal uses the term "Ishq" for it. Ishq is the higher form of love. Iqbal explains "Ishaq" in "Reconstruction of Religious Thought in Islam as:

The desire to assimilate, values and ideals and the endeavour to realize them. Love individualizes the lover as well as the beloved. The effort to realize the most unique individuality individualizes the seeker and implies the individuality of the sought, for nothing else would satisfy the nature of the seeker (Iqbal 169).

So by love the self comprehends all the implications of Reality. After the nourishment of desire, love of purpose mobilizes all the resources of the self to achieve the object of desire. The love of ideal thus keeps alive the desire and purifies the self of all other petty concerns by inculcating the singleness of purpose. In Iqbal's metaphysics, love always has an ideal----for example; Prophet Muhammad (P.B.U.H) is one major ideal for Muslim lover to attain:

In the Moslem's heart is the home of Muhammad,

All our glory is from the name of Muhammad

(The Secrets of the Self: Lines 351-52, P. 30)

And this love of the Prophet leads to the love of God:

Be a lover constant in devotion to thy beloved

That thou mayst cast thy noose and capture God

(The Secrets of the Self: Lines 425-26)

Hence the strength and potency of the self depends on the degree and depth of love. If one is steadfast in love, one can win all things and even "capture God".

The self further strengthened and purified by love then illuminates with an eternal light. It becomes one with the Divine Reality------The Self:

When the self I made strong by love

Its power rules the whole world

Its hand becomes God's hand,

The moon is split by its fingers.

(The Secrets of the Self: Lines 984-87, P. 43)

Here Iqbal alludes to a well known miracle of the Prophet (P.B.U.H) also mentioned in Quran (Ch. 54, V. 1). It is the beauty of Iqbal's poem that here this growth of the selfhood does not remain a poetic experience but he does prove its validity from the true historical instances. For Iqbal love is the desire to assimilate and absorb; so it is the love of God that ultimately involves absorption of the Divine Individuality by the self. It demands the assimilation of the attributes of God within the self. It brings out the creative potential of self.

In the next part of the poem Iqbal describes some further stages of growth of selfhood. He further tells that the self should be educated and trained in order to become perfect. It has to go through three stages. The self cannot be left unbridled. It must first cultivate the habit of obedience. Like camel the self should toil, and carry the burden of duty preservingly and with patience:

So wilt thou enjoy the best dwelling

Place, which is with God

Endeavour to obey, o heedless one!

Liberty is the fruit of compulsion.

(The Secrets of the Self: Lines 826-29, P. 73)

Without proper self-restraint and commitment of obedience, the freedom enjoyed by the self leads him to astray. He gives the example of music that it is just a discordant sound without a mechanical compulsion and it is to this compulsion that music owes its strength and its magic-power. The whole idea is beautifully expressed thus: 
The air becomes fragrant when it is imprisoned in the flower bud;

The perfume becomes musk when it is confined in the navel of the musk-dear.

The music is a controlled soul,

When the control is gone, the music is tuned into noise.

(The Secrets of the Self: Lines 832-35, P. 73-74)

The second stage that the self must pass through in order to become disciplined and strong is self-control. Iqbal emphasizes:

He that does not command himself

Becomes a receiver of commands from others

(The Secrets of the Self: Lines 853-54, P. 75)

Iqbal believes that belief in God and His commandments confers self-control. The belief, that there is no supreme power in the world except God, safeguards the self against a submission to fear of different kinds.

The third and the final stage of the development of the development of the self is Divine vicegerency that is attained when the self, as Iqbal explains in Reconstruction of Religious Thought in Islam, achieves a free personality, not by freeing himself from the fetters of law but by discovering the ultimate source of law within the depth of his consciousness" (Iqbal 171). At this stage the self reaches what is practically the condition of "the infinite passing into the loving embrace of the finite" (Iqbal in Nicholson xxix). It is the final destination of the self, the absorption of the Ultimate Self into the self:

Tis Sweet to be God's vicegerent in the world

And exercise sway over the elements

God's vicegerent is as the soul of the universe,

His being is the shadow to the Greatest Name,

(The Secrets of the Self: Lines 893-896, P. 79)

This stage of the vicegerency of God can be equated to the stage of mystical union with the Ultimate in case of Whitman. Though seemingly different ideas, their basic content is the same. In case of Whitman, it is the vision of the Absolute in mystical union that makes his self eternal and immortal and the most individual and unique. This confrontation with the Divine imbues him with the divine and superhuman power and Whitman assumes the role of the prophet. And here in Iqbal's world, the culminating point of the selfhood is to cultivate the attributes of God within the self to achieve the status of vicegerency. For such a realized self Iqbal uses the term "Perfect Man". Iqbal's "Perfect Man" with his fully developed self does not dissolve even when the Reality is seen face to face, Iqbal enumerates this idea in Reconstruction of Religious Thought in Islam as "The end of the ego's quest is not emancipation from the limitations of individuality: it is, on the other hand, a more precise definition of it" (Iqbal 171).

So the highest hierarchic rank---the vicegerency of God is achieved when man is able, not to be absorbed by Him and lose his identity, but to absorb within himself as many of God's attributes as possible.

Iqbal interprets in his own manner the doctrine of the Perfect Man. It advocates that every man is potentially a microcosm and that when he has become spiritually perfect, all the Divine attributes are displayed by him:

His hidden being is Life's mystery,

The unheard music of Life's harp

Nature travails in blood for generations

To compose the harmony of his personality

Appear, O rider of Destiny!

Appear, O light of the dark realm of change!

Illumine the scene of existence

(The Secrets of the Self: Lines 937-47)

For a Perfect Man the blessing of the selfhood, with attainment of the highest stage, range from the conquest of destiny to the spiritual conquest of the universe. Dr. A Schimmel puts it this way:

What he aims at, is not man as a measure of all things but as a being that grow the more perfect, the closer his connection with God is; it is man neither as an aesthetic superman who replaces a God who has died nor as the Perfect Man in the sense that he is but a visible aspect of God with whom he is essentially one-----but man as realizing the wonderful paradox of freedom and servant ship (Schimmel 382). 
So this Perfect Man of Iqbal is not a super-man nor he should realize his inner power. This is the key feature of his dynamic Sufism that has a note of universality in it. His Perfect Man does exhibit the qualities of Maslow's selfactualized person and Whitman's "Divine Average" but does excel in the manifestation of his individuality and his spiritual ideal. "His Perfect Man is democratic in origin---is a spiritual principle based on the assumption that every human being is centre of latent power, the possibilities of which are developed by cultivating a certain type of character" (Stemmer 29). His Perfect Man attains capacity to build a much vaster world in the depth of his own inner world and earns immortality through action and assertion rather than annihilation. Therefore, central to Iqbal's drama in the poem is his concern with human individuality. His vision is reminder of the universal commonalities of human diversity and the creative powers that may well be the most unifying force in the global family.

\section{References}

Ahmad, A. (1986). concept of self and self-sdentity. Lahore: Iqbal Academy.

Ali, S. A. (1988). Iqbal: his poetry and message. New Delhi: Deep \& Deep Publications.

Bilgrami, H.H. (1966). glimpses of Iqbal's mind and thought. Lahore: Sh. Mohd. Ashraf.

Cloninger, S. C. (1996). theories of personality: understanding persons. New Jersey: Prentice Hall.

Bradley, S. (1986). In: A Norton Critical Edition: leaves of grass. New Delhi: Prentice-Hall of India.

Chughatai, M. I. (2003). In: Iqbal: new dimensions. Lahore: Sang-e-Meel Publications.

Dar, B. A. (1971). a study in Iqbal's philosophy. Lahore: Sh. Ghulam Ali and Sons.

Elahi, M. (1986). the secrets of the self: English rendering of Iqbal's asrar-e-khudi. Lahore: Iqbal Academy.

Enver, I. H. (1944), the metaphysics of Iqbal. Lahore: Sh. Muhammad Ashraf.

Habib, N. (1985). In: versatile Iqbal. Lahore: Bazm-i-Iqbal.

Hafeez, M. I. (1971), the poet philosopher of Pakistan. New York: Columbia University press.

Hakim K. A. (1968). fikr-i-Iqbal. Lahore: Bazm-i-Iqbal.

Iqbal, A. M. (1986). the reconstruction of religious thought in Islam. Lahore: Institute of Islamic Culture.

Iqbal, M. (1978). the poet's vision and magic of words; an approach to Iqbal. Islamic Book Series.

Ishrat, W. (2003). hundred years of Iqbal's studies. Islamabad: Pakistan Academy of Letters.

Kemp, S. N. (1965). trans. the critique of pure reason. New York: St. Martin Press.

Khatoon, J. (1963). the place of God, man and universe in the philosophic system of Iqbal. Karachi: Industrial Printing Press.

Munawar, M. (2001). Iqbal: on human perfection. Lahore: Iqbal Academy.

Munawar, M. (1986). dimensions of Iqbal. Lahore: Iqbal Academy.

Nicholson, R. A. (1920). trans. the secrets of the self. Lahore: Sheikh Muhammad Ashraf.

Nurudin, A. S. (1978). Iqbal's attitude towards sufism and his unique philosophy of khudi- self. Dacca: Islamic Foundation.

Qaiser, N. (2003). Iqbal today. Lahore: Iqbal Academy.

Razzaqi, S. H. (1976). discourses of Iqbal. Lahore: Iqbal Academy.

Schimmel, A. (1965). Gabriel's wings. Lahore: Iqbal Academy.

Schimmel, A. (1975). mystical dimensions of Islam. Chapel Hill: University of North Carolina Press. 